\title{
Short-term associations between outdoor air pollution and visits to accident and emergency departments in London for respiratory complaints
}

\author{
R.W. Atkinson*, H.R. Anderson*, D.P. Strachan*, J.M. Bland*, S.A. Bremmer*, A. Ponce de Leon**
}

Short-term associations between outdoor air pollution and visits to accident and emergency departments in London for respiratory complaints. R.W. Atkinson, H.R. Anderson, D.P. Strachan, J.M. Bland, S.A. Bremner, A. Ponce de Leon. CERS Journals Ltd 1999. ABSTRACT: Many epidemiological studies have shown positive short-term associations between health and current levels of outdoor air pollution. The aim of this study was to investigate the association between air pollution and the number of visits to accident and emergency ( $A \& E$ ) departments in London for respiratory complaints. $A \& E$ visits include the less severe cases of acute respiratory disease and are unrestricted by bed availability.

Daily counts of visits to 12 London $A \& E$ departments for asthma, other respiratory complaints, and both combined for a number of age groups were constructed from manual registers of visits for the period 1992-1994. A Poisson regression allowing for seasonal patterns, meteorological conditions and influenza epidemics was used to assess the associations between the number of visits and six pollutants: nitrogen dioxide, ozone, sulphur dioxide, carbon monoxide, and particles measured as black smoke (BS) and particles with a median aerodynamic diameter of $<\mathbf{1 0} \mu \mathrm{m}$ (PM10).

After making an allowance for the multiplicity of tests, there remained strong associations between visits for all respiratory complaints and increases in $\mathrm{SO}_{2}:$ a $2.8 \%$ (95\% confidence interval (CI) 0.7-4.9) increase in the number of visits for a $18 \mu \mathrm{g} \cdot \mathrm{m}^{-3}$ increase (10th-90th percentile range) and a $3.0 \%(95 \%$ CI $0.8-5.2)$ increase for a 31 $\mu \mathrm{g} \cdot \mathrm{m}^{-3}$ increase in PM10. There were also significant associations between visits for asthma and $\mathrm{SO}_{2}, \mathrm{NO}_{2}$ and $\mathrm{PM10}$. No significant associations between $\mathrm{O}_{3}$ and any of the respiratory complaints investigated were found. Because of the strong correlation between pollutants, it was difficult to identify a single pollutant responsible for the associations found in the analyses.

This study suggests that the levels of air pollution currently experienced in London are linked to short-term increases in the number of people visiting accident and emergency departments with respiratory complaints.

Eur Respir J 1999; 13: 257-265.

\author{
*Dept of Public Health Sciences, St Ge- \\ orge's Hospital Medical School, Cranmer \\ Terrace, London, UK. **Dept de Estatís- \\ tica - IME/UERJ Rua São Francisco Xa- \\ vier, Maracanã Rio de Janeiro (RJ), Brazil. \\ Correspondence: R.W. Atkinson \\ Dept of Public Health Sciences \\ St George's Hospital Medical School \\ Cranmer Terrace \\ London SW17 ORE \\ UK \\ Fax: 441817253584
}

Keywords: Accident and emergency visits air pollution

respiratory complaints

time series

Received: April 251998

Accepted after revision October 91998

This work is part of an ongoing project funded by the Department of Health (JR 121/6267). Data collection was funded by the Pan Thames R\&D Consortium for Air Pollution and Respiratory Health.
In the first half of this century, very high levels of sulphur dioxide and particles produced from coal burning were responsible for severe health effects [1]. Today, the air pollution mixture is substantially different, with the predominant source being motor vehicles [2]. Many epidemiological studies have shown positive short-term associations between indices of health and the relatively low levels of outdoor air pollution currently experienced in major cities in Europe and the USA [3-10]. These indices have most commonly been daily counts of deaths and emergency admissions to hospitals. In the USA, studies have tended to concentrate on particles measured as those with a median aerodynamic diameter of $<10 \mu \mathrm{m}$ (PM10) and ozone. The European and more recent American studies have investigated a wider range of air pollutants, including nitrogen dioxide, $\mathrm{SO}_{2}$, and carbon monoxide. Studies in London for the years 1987/1988-1991/1992 have observed associations between daily mortality and black smoke (BS) and $\mathrm{O}_{3}$, and between respiratory hospital admissions and $\mathrm{O}_{3}[11,12]$.
A number of studies from the USA, Spain and Finland [13-21] have examined emergency room admissions (as opposed to visits), predominantly for asthma, with no consistent results emerging. The only study of emergency room visits in the UK [17] reported associations between $\mathrm{O}_{3}$ and $\mathrm{SO}_{2}$ and patterns of attendance for acute childhood wheezy episodes at one hospital over $1 \mathrm{yr}$. In the UK, visits to accident and emergency (A\&E) departments include some less severe cases of acute respiratory disease in addition to the more severe cases, which result in an emergency admission to hospital. Unlike hospital admissions, they are unrestricted by bed availability. The objective of this study was to assess the relationship between air polluion levels and visits to A\&E departments for respiratory complaints across London. By studying a large, densely populated city like London over a substantial period of time (1992-1994) we were able to obtain sufficient data to investigate visits for asthma and for other respiratory complaints separately as well as by age group whilst retaining sufficient statistical power. London has a comprehensive 
air-pollution monitoring network providing daily data on several air pollutants including CO and PM10 (available from 1992) [22].

\section{Methods}

Accident and emergency visits data

All A\&E departments in London were contacted to find out whether they kept manual registers of A\&E attendances and whether they were willing to allow us to extract data from them. Sixteen hospitals were suitable for inclusion in the study. All sixteen were selected as they represented approximately half of the number of A\&E departments in London, were geographically dispersed across London (fig. 1) and provided enough visits to perform analyses with sufficient statistical power. In each hospital, the manual registers used to record all visits to their A\&E department were scanned for visits for respiratory complaints. These complaints were (in order of priority where more than one complaint was coded): asthma, wheezing, inhaler request, chest infection, chronic obstructive lung disease (COLD), difficulty in breathing, cough and finally any other respiratory complaints such as croup, pleurisy and noisy breathing. The recorded complaint was that reported by the patient and not a clinical diagnosis. For each of these visits between January 1992 and December 1994, the presenting complaint together with the patient's age and the date of attendance were extracted from the manual registers. Daily counts of visits for asthma, for all other respiratory complaints and for the two together were computed for four age groupings: children aged $0-14$ yrs, adults $15-64$ yrs, elderly $\geq 65$ yrs (for other and all respiratory complaints only) and all ages.

\section{Air pollution and meteorological data}

Daily maximum and minimum temperature and 06:00 h and 15:00 h relative humidity measures at Holborn, central London, were obtained from the Meteorological Office. Daily average temperature and humidity measures were computed as the mean of the two respective values. Air pollution data were obtained from a number of monitoring stations across London according to availability and completeness during 1992-1994 and their geographical location. $\mathrm{NO}_{2}$ and $\mathrm{CO}$ data were obtained from three sites, $\mathrm{O}_{3}$ from two, and only one site provided PM10 data. BS and $\mathrm{SO}_{2}$ were obtained from five sites. Figure 1 indicates the location of the monitoring stations and the data they supplied. Where possible, missing values were estimated using a standard procedure [23], and single daily average values for each pollutant were calculated. Further detailed information on sites and measurement methods are provided in a contemporary review of UK air quality [22].

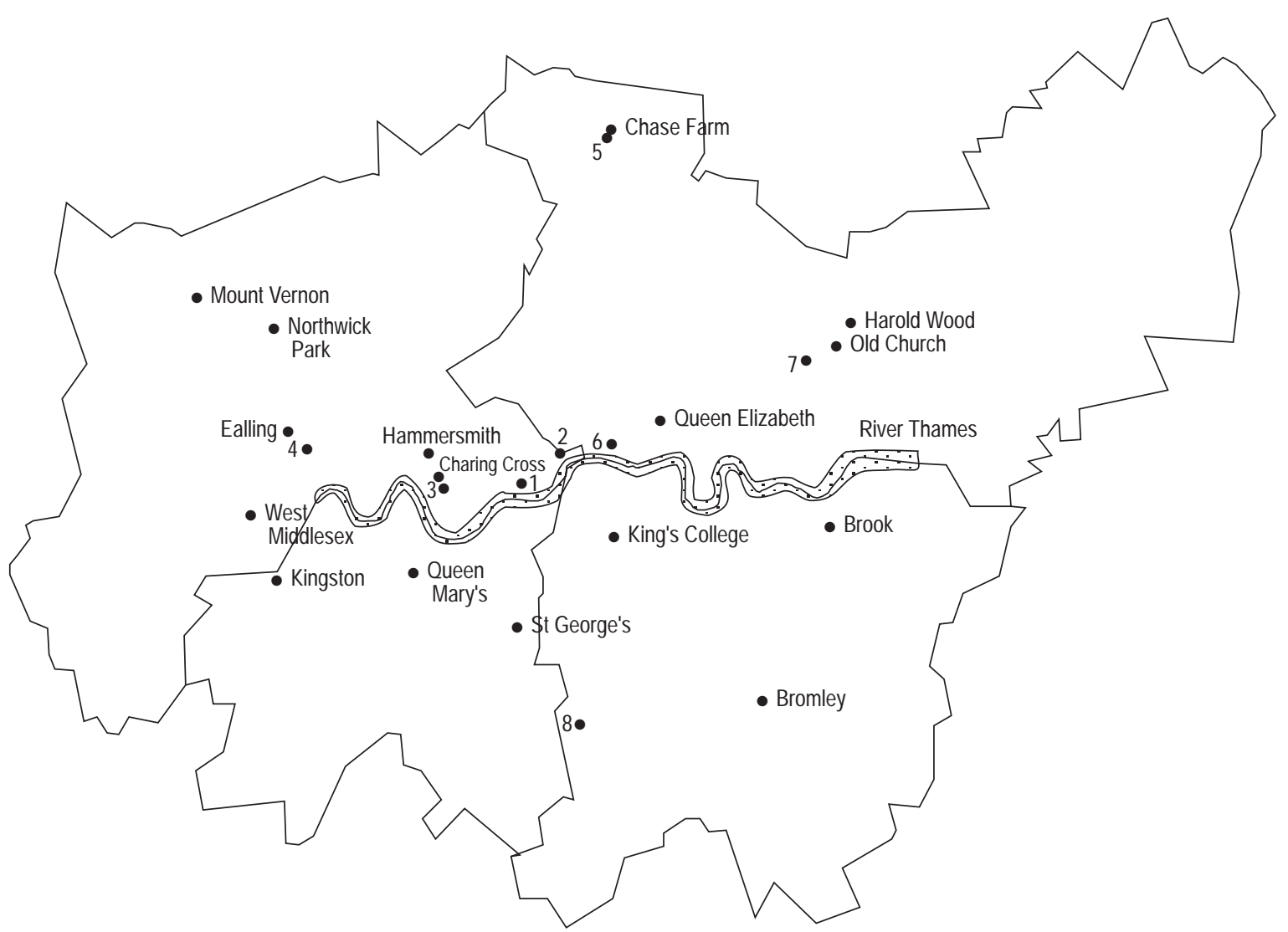

Fig. 1. - Locations of hospitals participating in the study and air-pollution monitoring stations providing data. The continuous lines represent the boundaries of the four Regional Health Authorities in London. The numbered dots represent the pollution monitoring sites providing data. Pollution monitoring sites: 1: Bridge Place $\left(\mathrm{NO}_{2}, \mathrm{O}_{3}, \mathrm{CO}\right)$; 2: Bloomsbury $\left(\mathrm{NO}_{2}, \mathrm{O}_{3}, \mathrm{CO}, \mathrm{PM} 10\right)$; 3: West London $\left(\mathrm{NO}_{2}, \mathrm{CO}\right)$; 4 : Acton (SO, $\left.\mathrm{BS}\right)$; 5 : Enfield (SO BS); 6: London city ( $\left.\mathrm{SO}_{2}, \mathrm{BS}\right)$; 7: Ilford ( $\left.\mathrm{SO}_{2}, \mathrm{BS}\right)$; 8: Croydon ( $\left.\mathrm{SO}_{2}, \mathrm{BS}\right)$. BS: black smoke; PM10: particles with a median aerodynamic diameter of 10 $\mu \mathrm{m}$. 


\section{Statistical methods}

The statistical analysis was based upon the methods developed by the "Air Pollution and Health: a European Approach" (APHEA) project [24]. The long-term trend, seasonality and day of week fluctuations of a series were determined using a number of statistical tools. Spectral analysis was used to determine the periodicity of the seasonal patterns and appropriate trigonometric variables constructed to account for them in a statistical model. The suitability of the statistical model was assessed using the overdispersion parameter, model deviance and plots of Pearson residuals, and any remaining serial correlation was assessed using the partial autocorrelation function. Daily counts of hospital admissions for influenza for the age group under study were included in the model to account for any possible confounding due to influenza epidemics in the community. Any remaining association between the observed counts and temperature and humidity was determined using plots of the model residuals against various measures of temperature and humidity. Alternative methods of modelling these meteorological variables (linear, quadratic, piece-wise, spline functions) were then compared using model-fit statistics and the most appropriate measure selected for inclusion in the model. Once the explanatory variables of the "core" model had been decided upon, an air pollution indicator was added. Poisson regression, allowing for overdispersion and autocorrelation [25] was used to determine the percentage change in the mean number of visits associated with an increase in the pollution measure. The 10th-90th percentile range in the pollutant was used as it represents well the range of pollution levels experienced in London during the analysis period and facilitates meaningful comparisons with the results for other pollutants. A predetermined set of daily pollution measures were tested, in turn, in the statistical model. For $\mathrm{SO}_{2}, \mathrm{BS}, \mathrm{CO}$ and PM10 the 24-h average was used, but for $\mathrm{NO}_{2}$ and $\mathrm{O}_{3}$, two daily measures were used: for $\mathrm{NO}_{2}$ the 24-h average and maximum one-hour measures, and for $\mathrm{O}_{3}$ the maximum eight-hour running average and maximum one-hour measures. These measures on the same day and 1,2 and 3 days prior to the day of the visit, termed single-day lags $0-3$, as well as cumulative lags, calculated as the mean of lags 0 and 1, lags $0-2$ and lags $0-3$ were tested. This process of "core" model building and then pollutant testing was repeated for each outcome and age group studied. For each pollutant, the most significant single-day lag, irrespective of the direction of the estimate, was selected for reporting purposes and for further analysis. Possible interactions between seasons were investigated using a dummy variable to indicate the season (warm season defined as April-September, cool season, October-March), and where appropriate, models with two pollutant measures were also examined to try and determine whether one pollutant was more important than another. Because of the large number of tests and the selective reporting and further testing of the most significant results, statistical significance was defined as $\mathrm{p}<0.01$. The usual $95 \%$ confidence limits have, however, been retained when presenting the results of the analyses in tables and graphically. For the purposes of simplifying the presentation and discussion, this paper focuses upon the results for the single day measures of pollution. The results for the cumulative lags are available on request. All statistical analyses were carried out using SAS statistical software (SAS Institute, Cary, NC, USA).

\section{Results}

The total entries scanned in the 16 hospitals numbered $2,170,941$, of which $121,610(5.6 \%)$ were for respiratory complaints. Four hospitals, one in central London and one each in the south west, north west and south east London, had incomplete manual registers and were excluded from the study leaving 98,685 visits for analysis. The remaining 12 hospitals in the study were representative of hospitals in the Greater London area in terms of both size and geographical distribution. There were 28,435 (28.8\%) vists for asthma during the three-year period. The largest single category of complaint was for the nonspecific "difficulty in breathing" with 38,371 visits $(38.9 \%)$, reflecting the selfreporting nature of the recorded complaint. The other categories were "wheeze" 6,228 (6.3\%), inhaler requests 649 (0.7\%), "chest infection" 9,697(9.8\%), COLD 1,613(1.6\%), "cough" 7,690 (7.8\%) and other respiratory complaints $6,002(6.1 \%)$. The majority of visits $42,276(42.8 \%)$, irrespective of complaint, were by children.

Figure 2 shows the time-series plots for the number of visits for all respiratory complaints together and for asthma only. The most striking feature of these plots are the large peaks in visits associated with a major thunderstorm on June 24, 1994 [26]. The mean number of daily visits for all respiratory complaints, asthma and other respiratory complaints are given in table 1 together with a summary of the distributions for the pollutants and meteorological measures used in the study.

\section{All respiratory complaints}

Table 2 gives the results for the most significant singleday measures of the six pollutants investigated for each age group for visits for all respiratory complaints. The results for the all-ages group for each single-day lag tested of the six pollutants are shown in figure 3 and

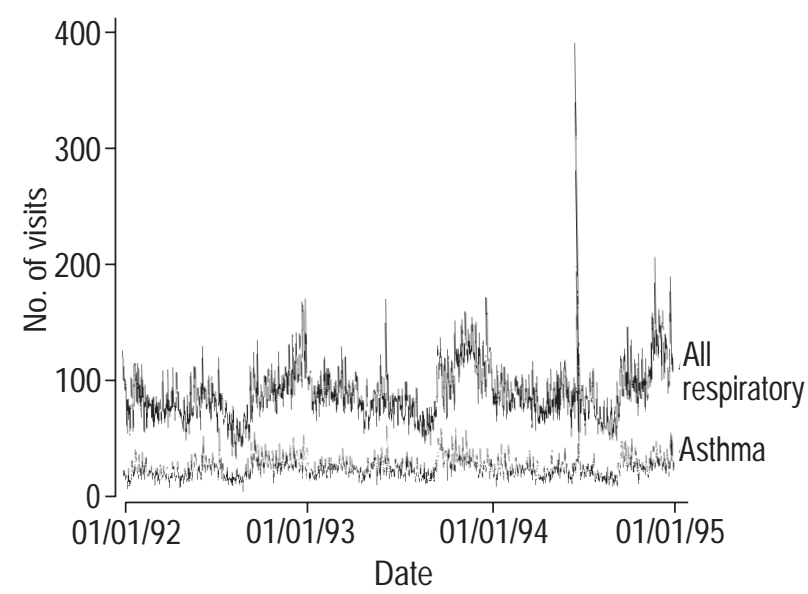

Fig. 2. - Daily number of visits to accident and emergency departments in London for all respiratory complaints and asthma between January 1992 and December 1994. 
Table 1. - Summary statistics for accident and emergency (A\&E) visits by complaint and age group and for pollution and meteorological variables between January 1992 and December 1994

\begin{tabular}{|c|c|c|c|c|c|c|c|c|c|}
\hline \multirow[b]{2}{*}{ Variable } & & \multirow[b]{2}{*}{$\mathrm{n}$} & \multirow[b]{2}{*}{ Mean } & \multirow[b]{2}{*}{ SD } & \multirow[b]{2}{*}{ Min } & \multicolumn{3}{|c|}{ Percentile } & \multirow[b]{2}{*}{ Max } \\
\hline & & & & & & 10th & 50th & 90th & \\
\hline \multicolumn{10}{|c|}{ A\&E complaints (daily number of visits) } \\
\hline \multirow[t]{4}{*}{ All respiratory } & All ages yrs & 1096 & 90.0 & 25.1 & 34 & 64 & 86 & 121 & 390 \\
\hline & $0-14$ & 1096 & 38.6 & 15.9 & 10 & 21 & 36 & 59 & 146 \\
\hline & $15-64$ & 1096 & 29.2 & 11.2 & 10 & 20 & 28 & 39 & 278 \\
\hline & $\geq 65$ & 1096 & 19.3 & 6.1 & 5 & 12 & 18.5 & 27 & 49 \\
\hline \multirow[t]{3}{*}{ Asthma } & All ages yrs & 1096 & 25.9 & 9.4 & 6 & 16 & 25 & 38 & 128 \\
\hline & $0-14$ & 1096 & 12.0 & 5.8 & 1 & 5 & 11 & 19 & 37 \\
\hline & $15-64$ & 1096 & 11.4 & 5.3 & 1 & 6 & 11 & 17 & 96 \\
\hline \multirow[t]{4}{*}{ Other respiratory } & All ages yrs & 1096 & 64.1 & 18.8 & 19 & 45 & 61 & 88 & 262 \\
\hline & $0-14$ & 1096 & 26.6 & 12.4 & 5 & 14 & 24 & 42 & 115 \\
\hline & $15-64$ & 1096 & 17.8 & 7.5 & 5 & 11 & 17 & 24 & 182 \\
\hline & $\geq 65$ & 1096 & 17.6 & 5.7 & 3 & 11 & 17 & 25 & 42 \\
\hline \multicolumn{10}{|c|}{ Pollutants (daily concentrations) } \\
\hline \multicolumn{2}{|l|}{$\mathrm{NO}_{2} 1 \mathrm{~h} \mathrm{ppb}$} & 1096 & 50.3 & 17.0 & 22.0 & 34.3 & 47.0 & 70.3 & 224.3 \\
\hline \multicolumn{2}{|l|}{$\mathrm{O}_{3} 8 \mathrm{~h} \mathrm{ppb}$} & 1067 & 17.5 & 11.5 & 1.9 & 4.4 & 16.0 & 30.1 & 79.9 \\
\hline \multicolumn{2}{|l|}{$\mathrm{SO}_{2} 24 \mathrm{~h} \mu \mathrm{g} \cdot \mathrm{m}^{-3}$} & 1096 & 21.2 & 7.8 & 7.4 & 13.0 & 19.8 & 31.0 & 82.2 \\
\hline \multicolumn{2}{|l|}{$\mathrm{CO} 24 \mathrm{~h} \mathrm{ppm}$} & 1096 & 0.8 & 0.4 & 0.2 & 0.5 & 0.7 & 1.3 & 5.6 \\
\hline \multicolumn{2}{|l|}{ PM10 $24 \mathrm{~h} \mu \mathrm{g} \cdot \mathrm{m}^{-3}$} & 997 & 28.5 & 13.7 & 6.8 & 15.8 & 24.8 & 46.5 & 99.8 \\
\hline \multicolumn{2}{|l|}{$\mathrm{BS} 24 \mathrm{~h} \mu \mathrm{g} \cdot \mathrm{m}^{-3}$} & 1096 & 12.7 & 7.9 & 1.6 & 5.5 & 10.8 & 21.6 & 69.8 \\
\hline \multicolumn{10}{|c|}{ Meteorological measures } \\
\hline \multicolumn{2}{|c|}{ Temperature ${ }^{\circ} \mathrm{C}$} & 1096 & 11.9 & 5.0 & -0.8 & 5.6 & 11.7 & 18.6 & 25.5 \\
\hline \multicolumn{2}{|l|}{ Humidity $\%$} & 1090 & 70.4 & 11.0 & 33.0 & 56.0 & 70.0 & 85.0 & 97.0 \\
\hline
\end{tabular}

BS: black smoke; PM10: particles with a median aerodynamic diameter of $<10 \mu \mathrm{m}$. ppb: parts per billion; ppm: parts per million.

illustrate the degree of consistency, in terms of the direction and magnitude of their associations, across the lags investigated.

Increases in visits to A\&E departments for respiratory complaints were associated with increases in daily levels of the six pollutants studied. The associations with $\mathrm{SO}_{2}$ and PM10 were statistically significant, small in magnitude (approximately a 3\% increase in the number of visits for a 10th-90th percentile increase in the pollutant), and were slightly more consistent for $\mathrm{SO}_{2}$ than for PM10. The $\mathrm{SO}_{2}$ associations were found to be stronger (smaller p-values and larger effect estimates) for children: lag 2 days $6.01 \%$ (95\% CI 2.98-9.12), $\mathrm{p}=0.00008$. In adults, there was a strong association between visits with the lag 1 day measure of PM10, 5.18\% (95\% CI 2.06-8.39), $\mathrm{p}=0.001$. There was also some evidence for a significant association with BS, again at lag 1 day but none for $\mathrm{O}_{3}$. There were no significant seasonal differences in these results (data not shown). $\mathrm{SO}_{2}$ and PM10 measures are closely correlated (Pearson correlation coefficient $=0.6$ ). Results of a two-pollutant model containing both $\mathrm{SO}_{2}$ and PM10 measures suggested that it was not possible to determine whether only one of these pollutants was responsible for both observed single pollutant model associations (data not shown).

A significant association between visits for respiratory complaints and CO was found in the elderly: $4.29 \%(95 \%$ CI 1.15-7.54), $\mathrm{p}=0.007$. This result was largely unaffected by the addition of any of the other pollutants into the model (data not shown).

\section{Asthma}

There were consistent and highly statistically significant associations between asthma visits and increases in daily levels of $\mathrm{SO}_{2}, \mathrm{NO}_{2}$ and PM10 and, to a lesser extent, $\mathrm{CO}$ and BS. Table 3 summarizes these results for all age groups investigated, and figure 4 shows the results, for the all-ages group, for each lag of the single day measures of the six pollutants investigated. Particularly strong associations with $\mathrm{SO}_{2}$ and $\mathrm{NO}_{2}$ were found in children: $\mathrm{SO}_{2}$, lag 1 day, $9.92 \%$ (95\% CI 4.75-15.34), $\mathrm{p}=0.0001$; and $\mathrm{NO}_{2}$, 1-h measures, lag 1 day, 8.97\% (95\% CI 4.3913.74), $\mathrm{p}=0.00009$. PM10 was associated with increases in visits for asthma in each of the three age groups studied. There was no evidence that $\mathrm{O}_{3}$ was associated with visits for asthma. There was strong evidence of a significant seasonal difference in the association between asthma visits and $\mathrm{NO}_{2}$ in children, $\mathrm{p}=0.009$; and during the warm season, the association was very strong at $19.70 \%(95 \%$ CI $10.61-29.53), p=0.000008$. Table 4 presents the results of the two-pollutant models for asthma in children. They show that both the magnitude and statistical significance of the single pollutant model results for $\mathrm{NO}_{2}, \mathrm{SO}_{2}$ and $\mathrm{PM} 10$ were all reduced by the addition of another of these pollutants to the statistical model. This indicates that none of these three pollutants acted independently of the others. However, a two-pollutant model by season suggested that the $\mathrm{NO}_{2}$ association was independent of the $\mathrm{SO}_{2}$ association in the warmer months (data not shown). Broadly similar results were obtained for adults and all ages (full details on request from the authors).

\section{All other respiratory complaints}

For respiratory complaints other than asthma, both $\mathrm{SO}_{2}$ and PM10 showed significant associations with an increased number of visits. However, the pattern of results 
Table 2. - Summary of single pollutant results for all respiratory complaints

\begin{tabular}{|c|c|c|c|c|}
\hline $\begin{array}{l}\text { Age } \\
\text { group }\end{array}$ & Pollutant & Lag & $\begin{array}{l}\% \text { change in visit No. } \\
(95 \% \mathrm{CI})\end{array}$ & p-value \\
\hline \multirow[t]{6}{*}{ All ages } & $\mathrm{NO}_{2}$ & 1 & $1.20(-0.57-3.00)$ & 0.2 \\
\hline & $\mathrm{O}_{3}$ & 1 & $1.65(-0.92-4.30)$ & 0.2 \\
\hline & $\mathrm{SO}_{2}$ & 1 & $2.81(0.72-4.93)$ & 0.008 \\
\hline & $\mathrm{CO}$ & 1 & $0.76(-0.83-2.38)$ & 0.3 \\
\hline & PM10 & 1 & $2.97(0.83-5.16)$ & 0.006 \\
\hline & BS & 1 & $1.63(-0.24-3.54)$ & 0.09 \\
\hline \multirow[t]{6}{*}{ Children } & $\mathrm{NO}_{2}$ & 1 & $2.17(-0.49-4.91)$ & 0.1 \\
\hline & $\mathrm{O}_{3}$ & 2 & $-3.28(-7.20-0.80)$ & 0.1 \\
\hline & $\mathrm{SO}_{2}$ & 2 & $6.01(2.98-9.12)$ & 0.00008 \\
\hline & $\mathrm{CO}$ & 1 & $2.92(0.60-5.30)$ & 0.01 \\
\hline & PM10 & 1 & $3.86(0.55-7.27)$ & 0.02 \\
\hline & BS & 1 & $3.72(0.98-6.53)$ & 0.007 \\
\hline \multirow[t]{6}{*}{ Adults } & $\mathrm{NO}_{2}$ & 2 & $1.87(-0.69-4.49)$ & 0.2 \\
\hline & $\mathrm{O}_{3}$ & 0 & $-2.54(-5.68-0.71)$ & 0.1 \\
\hline & $\mathrm{SO}_{2}$ & 2 & $2.72(-0.18-5.70)$ & 0.07 \\
\hline & $\mathrm{CO}$ & 1 & $2.15(-0.27-4.63)$ & 0.08 \\
\hline & PM10 & 2 & $5.18(2.06-8.39)$ & 0.001 \\
\hline & BS & 1 & $3.55(0.81-6.36)$ & 0.01 \\
\hline \multirow[t]{6}{*}{ Elderly } & $\mathrm{NO}_{2}$ & 0 & $3.97(0.51-7.55)$ & 0.02 \\
\hline & $\mathrm{O}_{3}$ & 2 & $6.77(0.81-13.08)$ & 0.03 \\
\hline & $\mathrm{SO}_{2}$ & 1 & $-1.82(-5.72-2.25)$ & 0.4 \\
\hline & $\mathrm{CO}$ & 0 & $4.29(1.15-7.54)$ & 0.007 \\
\hline & PM10 & 1 & $-2.85(-6.91-1.39)$ & 0.2 \\
\hline & BS & 1 & $-3.70(-7.25--0.02)$ & 0.05 \\
\hline
\end{tabular}

Associations are expressed as the percentage change (95\% confidence interval (CI)) in the number of accident and emergency visits for a 10th to a 90th percentile change in each pollutant presented at its most significant single-day lag. All p-values have been rounded to one significant digit. BS: black smoke; PM10: particles with a median aerodynamic diameter of $<10$ $\mu \mathrm{m}$.

across the different measures and lags and the levels of statistical significance obtained gave a less convincing message than for asthma (full details on request from the authors).

\section{Discussion}

This study found significant associations between the number of daily visits to A\&E departments and measures of outdoor air pollutants such as $\mathrm{SO}_{2}, \mathrm{NO}_{2}$, and PM10.

In evaluating the results of this study, a greater emphasis has been placed on results which are highly significant, $\mathrm{p}<0.01$, and consistent in terms of direction, magnitude and statistical significance across the various lags of each pollutant tested. In this way, we have attempted to avoid placing too much importance on isolated significant associations amongst a large number of statistical tests.

In studies of this type, a key issue is the appropriate control for confounding variables. The statistical models were constructed following a standardized methodology and then checked to ensure that the model fit was satisfactory. Particular attention was paid to the modelling of temperature and humidity. It is unlikely, therefore, that either temperature or humidity is confounding the relation-

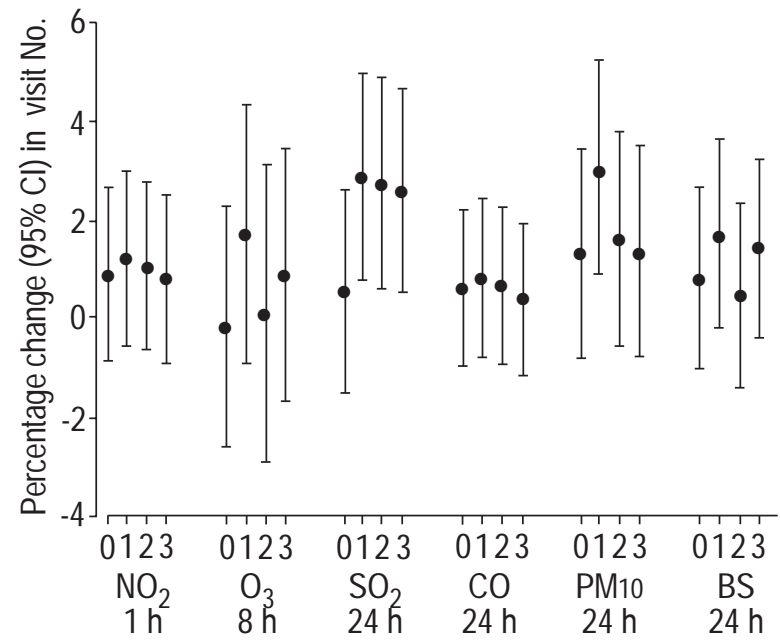

Fig. 3. - Single pollutant model results for all respiratory complaints. Associations are expressed as a percentage change $(95 \%$ confidence interval (CI)) in number of accident and emergency visits for a 10th to a 90th percentile change in each pollutant. Results for each lag tested, lags 0-3, for each pollutant are shown. BS: black smoke; PM10: particles with a median aerodynamic diameter of $<10 \mu \mathrm{m}$.

ships with air pollution. The unusual environmental conditions associated with the thunderstorm in June 1994 were accounted for by including dummy variables in the statistical models.

A limitation of the present study is that the population exposure to outdoor air pollution across London is derived from only a few monitoring stations. The correlations between sites for $\mathrm{NO}_{2}, \mathrm{O}_{3}$ and $\mathrm{CO}$ are all positive and high, at $0.7-0.96$, suggesting that whilst levels may vary between locations, the short-term temporal pattern of fluctuations

Table 3. - Summary of single pollutant results for asthma visits

\begin{tabular}{llccl}
\hline $\begin{array}{l}\text { Age } \\
\text { group }\end{array}$ & Pollutant & Lag & $\begin{array}{c}\text { \% change in visit No. } \\
(95 \% \mathrm{CI})\end{array}$ & p-value \\
\hline All ages & $\mathrm{NO}_{2}$ & 0 & $4.37(1.32-7.52)$ & 0.005 \\
& $\mathrm{O}_{3}$ & 1 & $2.67(-1.66-7.21)$ & 0.2 \\
& $\mathrm{SO}_{2}$ & 1 & $4.95(1.53-8.48)$ & 0.004 \\
& $\mathrm{CO}$ & 1 & $3.32(0.56-6.16)$ & 0.02 \\
& $\mathrm{PM} 10$ & 1 & $5.35(1.77-9.05)$ & 0.003 \\
& $\mathrm{BS}$ & 2 & $2.85(-0.21-6.01)$ & 0.07 \\
Children & $\mathrm{NO}_{2}$ & 1 & $8.97(4.39-13.74)$ & 0.00009 \\
& $\mathrm{O}_{3}$ & 0 & $-5.23(-12.07-2.15)$ & 0.2 \\
& $\mathrm{SO}_{2}$ & 1 & $9.92(4.75-15.34)$ & 0.0001 \\
& $\mathrm{CO}$ & 0 & $4.13(-0.11-8.54)$ & 0.06 \\
& $\mathrm{PM} 10^{4}$ & 2 & $7.41(2.10-13.00)$ & 0.006 \\
& $\mathrm{BS}$ & 2 & $4.57(-0.04-9.40)$ & 0.05 \\
& $\mathrm{NO}$ & 1 & $4.44(0.14-8.92)$ & 0.04 \\
& $\mathrm{O}_{3}$ & 0 & $-4.11(-10.39-2.61)$ & 0.2 \\
& $\mathrm{SO}_{2}$ & 1 & $4.19(-0.53-9.13)$ & 0.08 \\
& $\mathrm{CO}$ & 1 & $4.41(0.46-8.52)$ & 0.03 \\
& $\mathrm{PM}_{10}$ & 1 & $7.83(2.83-13.07)$ & 0.002 \\
& $\mathrm{BS}$ & 1 & $5.14(0.72-9.75)$ & 0.02 \\
\hline
\end{tabular}

Associations are expressed as the percentage change (95\% confidence interval (CI)) in the number of accident and emergency visits for a 10th to a 90th percentile change in each pollutant presented at its most significant single-day lag. All pvalues have been rounded to one significant digit. BS: black smoke; PM10: particles with a median aerodynamic diameter of $<10 \mu \mathrm{m}$. 


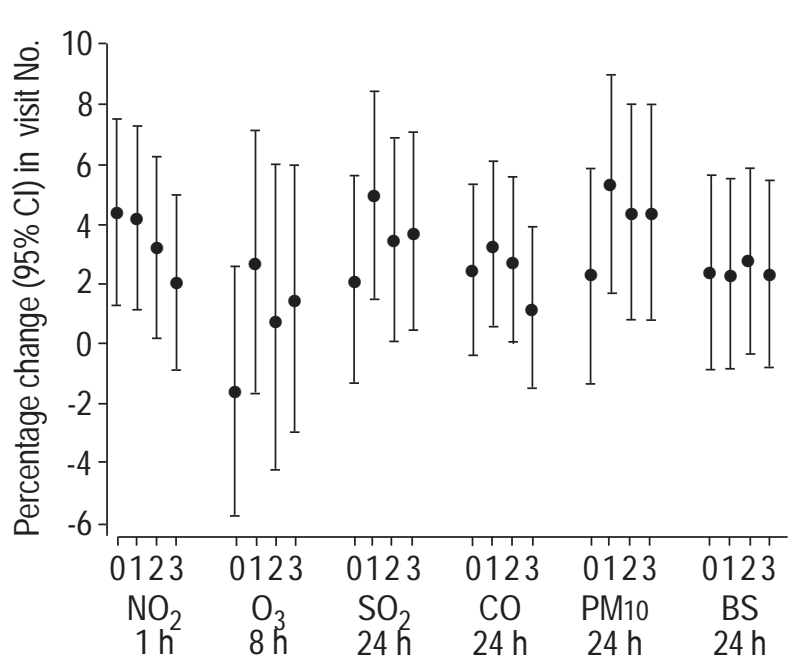

Fig. 4. - Single pollutant model results for all asthma complaints. Associations are expressed as percentage change $(95 \%$ confidence interval (CI)) in number of accident and emergency visits for a 10th to a 90th percentile change in each pollutant presented at its most significant single day lag. Results for each lag tested, lags $0-3$, for each pollutant are shown. BS: black smoke; PM10: particles with a median aerodynamic diameter of $<10 \mu \mathrm{m}$.

do not. Correlations between the five sites providing $\mathrm{SO}_{2}$ and BS data are smaller, in the range $0.5-0.8$ for BS and $0.2-0.5$ for four of the five $\mathrm{SO}_{2}$ sites. The sites providing $\mathrm{BS}$ and $\mathrm{SO}_{2}$ data are sampling sites, rather than continuously monitored and are geographically dispersed across London rather than co-located or in close proximity. Either of these factors may be responsible for the lower correlation between sites.

There have been a number of epidemiological studies of emergency room admissions and air pollution, and a summary of some of these studies is given in table 5. They focus mostly on asthma and address a variety of pollutants, age ranges and time periods as well as utilizing a range of statistical methods. No consistent picture emerges from their results. Statistically significant associations with visits for asthma and $\mathrm{O}_{3}, \mathrm{SO}_{2}, \mathrm{NO}_{2}, \mathrm{PM} 10$ and $\mathrm{BS}$ are all reported. There are a number of distinct differences between these studies and the work reported here. Firstly, the size of the population at risk in London was considerably larger than in other studies. Secondly, the power of our study, determined by the mean number of events per day and the time period covered, was larger than in other studies. Finally, the complaint used in our study was that stated by the subject at presentation and did not represent the clinical diagnosis after assessment in the A\&E department. This enabled us to record the full number of visits to A\&E, irrespective of severity, but at the expense of a large number of nonspecific respiratory complaints such as "wheezing" and "difficulty in breathing" being recorded. STIEB et al. [19] recorded both the presenting complaint and the diagnosis recorded by the physician. They concluded that whilst the majority of asthma presentations were for asthma, they did not represent the true incidence of asthma. It is possible, therefore, that we have underrecorded the true incidence of asthma. If visits for asthma are associated with air pollution levels, then the effect of this underrecording is

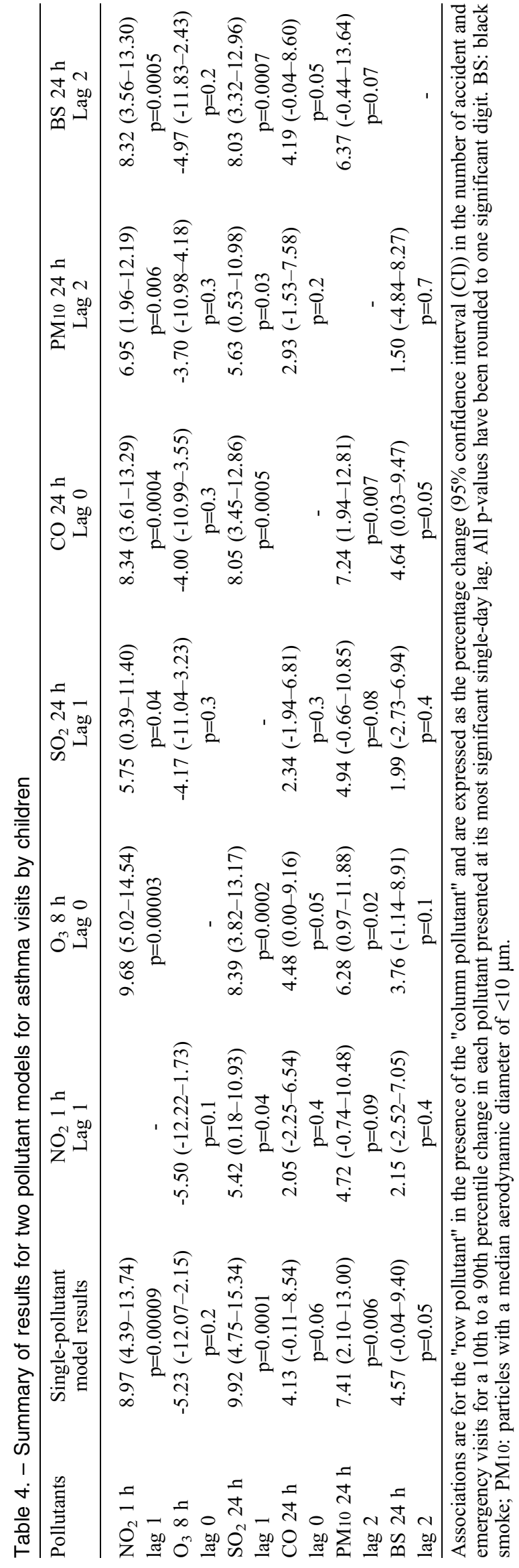


Table 5. - Summary of published results for time series analyses of emergency room visits for asthma and other respiratory complaints

\begin{tabular}{|c|c|c|c|c|c|c|c|c|}
\hline First author [Ref.] & $\begin{array}{l}\text { Year of } \\
\text { publica- } \\
\text { tion }\end{array}$ & Setting & Period covered & $\begin{array}{l}\text { Outcome } \\
\text { measure }\end{array}$ & $\begin{array}{l}\text { Analysis } \\
\text { method }\end{array}$ & $\begin{array}{l}\text { Main } \\
\text { pollutants }\end{array}$ & Main findings & Comments \\
\hline Bates [13] & 1990 & $\begin{array}{l}\text { Vancouver, } \\
\text { Canada }\end{array}$ & 1984-1986 & $\begin{array}{l}\text { Asthma, } 9.5 \cdot \text { day }^{-1} \\
\text { All ages }\end{array}$ & $\begin{array}{l}\text { Univariate } \\
\text { correlation } \\
\text { coefficients }\end{array}$ & $\mathrm{O}_{3}, \mathrm{SO}_{2}, \mathrm{NO}_{2}$ & $\begin{array}{l}\mathrm{S}: \text { adults, } \mathrm{SO}_{2} \text { lag } 0 \text { days } \\
\mathrm{r}=0.12 \mathrm{p}<0.01 \\
\mathrm{~W}: \text { elderly, } \mathrm{SO}_{2} \text { lag } 1 \\
\text { days } \mathrm{r}=0.15 \mathrm{p}<0.001 \\
\text { (lags } 0 \text { and } 2 \text { also) }\end{array}$ & $\begin{array}{l}\text { Significant correlation } \\
\text { for respiratory visits and } \\
\mathrm{SO}_{2} / \mathrm{NO}_{2} \text { also }\end{array}$ \\
\hline Cody [14] & 1992 & $\begin{array}{l}\text { New Jersey, } \\
\text { USA }\end{array}$ & May 1988-Aug 1989 & $\begin{array}{l}\text { Asthma, } 3.6 \cdot \text { day }^{-1} \\
\text { All ages }\end{array}$ & MLR & $\mathrm{O}_{3}$ & $\begin{array}{l}\mathrm{O}_{3} \text { coefficient } 20.3 \\
(\mathrm{seM} 7.2) \mathrm{p}=0.005\end{array}$ & \\
\hline WeISEL [21] & 1995 & $\begin{array}{l}\text { New Jersey, } \\
\text { USA }\end{array}$ & Summer 1986-1990 & Asthma & MLR & $\mathrm{O}_{3}$ & $\mathrm{O}_{3}$ associated & \\
\hline SCHWARTZ [15] & 1993 & Seattle, USA & Sept 1989-Sept 1990 & $\begin{array}{l}\text { Asthma, } 7.1 \cdot \text { day }^{-1} \\
\text { All ages }\end{array}$ & PR & PM10 & $\begin{array}{l}\text { PM10 mean lags } 0-4 \\
30 \mu \mathrm{g} \cdot \mathrm{m}^{-3} \\
\text { RR } 1.12(1.01-1.06)\end{array}$ & $\begin{array}{l}\text { Control for temperature, } \\
\text { humidity, seasonality, } \\
\text { serial correlation and } \\
\text { overdispersion }\end{array}$ \\
\hline Castellsague [16] & 1995 & $\begin{array}{l}\text { Barcelona, } \\
\text { Spain }\end{array}$ & 1985-1989 & $\begin{array}{l}\text { Asthma, all ages } \\
\text { S: } 2.7 \cdot \text { day }^{-1} \\
\text { W: } 3.9 \cdot \text { day }^{-1}\end{array}$ & $\mathrm{PR}$ & $\begin{array}{l}\mathrm{O}_{3}, \mathrm{BS}, \mathrm{NO}_{2} \\
\mathrm{SO}_{2}\end{array}$ & $\begin{array}{l}\text { S: BS lag } 0,25 \mu \mathrm{g} \cdot \mathrm{m}^{-3} \\
\mathrm{RR} 1.08(1.01-1.16) \\
\mathrm{NO}_{2} \text { lag } 0,25 \mu \mathrm{g} \cdot \mathrm{m}^{-3} \\
\text { RR } 1.05(1.01-1.08)\end{array}$ & $\begin{array}{l}\text { Similar results in winter } \\
\text { for } \mathrm{NO}_{2} \text { only. } \\
\text { Cumulative measures } \\
\text { gave larger RR. } \\
\text { Confounder control as } \\
\text { per ScHWARTz [15] }\end{array}$ \\
\hline BUCHDAHL [17] & 1996 & London, UK & Mar 1992-Feb 1993 & $\begin{array}{l}\text { Wheeze, children } \\
0-16 \text { yrs (median 2) }\end{array}$ & PR & $\mathrm{O}_{3}, \mathrm{NO}_{2}, \mathrm{SO}_{2}$ & $\begin{array}{l}\mathrm{SO}_{2} \text { and } \mathrm{O}_{3} \text { associated } \\
\text { wheeze }\end{array}$ & $\begin{array}{l}\text { "U" shape for } \mathrm{O}_{3} \\
\text { response. No day-of- } \\
\text { week adjustment }\end{array}$ \\
\hline Delfino $[18]$ & 1997 & $\begin{array}{l}\text { Montreal, } \\
\text { Quebec }\end{array}$ & June-Sept 1992 and 1993 & $\begin{array}{l}\text { All respiratory } \\
98 \cdot \text { day }^{-1}, \text { all ages. } \\
\text { Other ages also }\end{array}$ & MLR & $\begin{array}{l}\mathrm{O}_{3}, \mathrm{H}^{+}, \mathrm{PM}_{10} \\
\mathrm{PM} 2.5, \mathrm{SO}_{4}\end{array}$ & $\begin{array}{l}\mathrm{O}_{3} \text { and } \mathrm{PM} 10 \text { associated } \\
\text { with } \geq 65 \text { yrs }\end{array}$ & $\begin{array}{l}\text { Results based on one } \\
\text { summer }\end{array}$ \\
\hline Stieb [19] & 1996 & $\begin{array}{l}\text { Saint John, } \\
\text { New Brunswick, } \\
\text { Canada }\end{array}$ & May-Sept 1984-1992 & $\begin{array}{l}\text { Asthma, } 1.5 \cdot \text { day }^{-1} \\
\text { All ages }\end{array}$ & PR & $\begin{array}{l}\mathrm{O}_{3}, \mathrm{SO}_{2}, \mathrm{NO}_{2} \\
\text { TSP, } \mathrm{SO}_{4}\end{array}$ & $\begin{array}{l}\mathrm{O}_{3} \text { and asthma all ages, } \\
\text { adults, not children }\end{array}$ & $\begin{array}{l}\text { Presenting complaint } \mathrm{O}_{3} \\
\text { associated non-linear. } \\
\text { Invariant to co-pollutants. } \\
\text { Little PM10 data }\end{array}$ \\
\hline Rossi [20] & 1993 & Oulu, Finland & Oct 1985-Sept 1986 & $\begin{array}{l}\text { Asthma, adults } \\
15-85,<1 \cdot \text { day }^{-1}\end{array}$ & $\begin{array}{l}\text { MLR and } \\
\text { DA }\end{array}$ & $\begin{array}{l}\mathrm{SO}_{2}, \mathrm{NO}_{2}, \mathrm{TSP}, \\
\mathrm{H}_{2} \mathrm{~S}\end{array}$ & $\begin{array}{l}\mathrm{NO}_{2} \text { associated with } \\
\text { asthma, all year and } \\
\text { cool season }\end{array}$ & $\begin{array}{l}\text { Basic modelling, low } \\
\text { counts, } 1 \mathrm{yr}\end{array}$ \\
\hline
\end{tabular}

MLR: multiple linear regression; PR: Poisson regression; DA: discriminant analysis; S: summer months; W: winter months; RR: relative risk; BS: black smoke; SO ${ }_{4}$ : sulphates; TSP: tota suspended particles; $\mathrm{H}+$ : aerosol strong acidity; PM10: particles with a median aerodynamic diameter of $<10 \mu \mathrm{m}$; PM2.5: particles with a median aerodynamic diameter of $2.5 \mu \mathrm{m}$. 
likely to be a bias towards the null, leading to underestimates of the effect of the air pollutants on asthma.

Statistically significant associations between air pollution and visits to A\&E departments for respiratory complaints were found. The associations with $\mathrm{NO}_{2}$ and $\mathrm{SO}_{2}$ in children presenting with asthma are particularly strong. There have been few time-series studies of children and asthma using these more advanced statistical techniques so comparisons with other findings are difficult. The $\mathrm{NO}_{2}$ findings in adults are comparable with those of CASTELLSAGUE et al. [16], but not STIEB et al. [19] or BUCHDAHL et al. [17]. There is some evidence that aeroallergens may have an enhanced effect in the presence of $\mathrm{NO}_{2}$ and/or $\mathrm{SO}_{2}$ [27]. To assess this possibility, daily measures of grass, birch, nettle and oak pollens were added to the children's asthma model and checked for statistical significance. None of the pollen measures was statistically significant at the 5\% level. This quick assessment suggests that pollen levels do not influence the air pollution results. However, further work is required to investigate possible pollution/ pollen interactions as well as the role of fungal spores. There was a significant seasonal difference in the children's $\mathrm{NO}_{2}$ result with a very strong association in the warmer months. One possible explanation is that outdoor exposure more accurately reflects real personal exposure during the warmer months compared to the cooler months, resulting in stronger, as well as more significant, associations.

CASTEllsague et al. [16] also reported significant associations between asthma and BS in the summer months, a result not replicated in this study. We did, however, find associations with PM10 and asthma in children, adults and the all-ages group. SchwARTz et al. [15] investigated PM10 in Seattle, USA and found significant associations with asthma visits for an all-ages group. DeLFino et al. [18] reported similar findings for PM10 and visits for all respiratory complaints by the elderly.

Our finding that $\mathrm{SO}_{2}$ and $\mathrm{A} \& \mathrm{E}$ attendances for asthma are associated is consistent with the work of BATES et al. [13] and BuChDAHL et al. [17], but not CASTELLSAGUe et al. [16] or STIEB et al. [19]. However, the former study, conducted in 1990, used simple statistical methods, whereas BUCHDAHL et al. [17] studied only wheezing episodes at a single hospital for $1 \mathrm{yr}$.

In the present study, we have been unable to separate the effects of PM10 and $\mathrm{SO}_{2}$ on asthma visits. In two-pollutant models for asthma, the magnitude and statistical significance of the single pollutant associations were reduced by the addition of the other pollutant. It is possible that the $\mathrm{SO}_{2}$ measures were a surrogate for exposure to fine sulphate particles, which would also have been included in the PM10 measurements. A small amount of sulphate data (for 493 days between 1992 and 1994) were available, and these were used to investigate the association between visits for asthma and fine sulphate particles. For visits for asthma by children and the all-ages group, none of the single day measures of sulphate investigated (lags 0-3) was statistically significant, even at the less stringent $5 \%$ level. This result is perhaps not so surprising given the low correlation between $\mathrm{SO}_{2}$ and sulphate (Pearson correlation coefficient $=0.4$ ). As expected, the correlation between PM10 and sulphate is quite high, at 0.7. These results suggest that the above assumptions that the $\mathrm{SO}_{2}$ associations with visits for asthma are surrogates for associations with fine sulphate particles are incorrect.
Ozone has been associated with visits for asthma and respiratory attendances $[14,17-19,21]$ as well as for emergency hospital admissions in London [11], so it is surprising that no evidence for an association with $\mathrm{O}_{3}$ was found in the present study. In fact, the lack of any association with $\mathrm{O}_{3}$ was a consistent finding across all outcome measures and age groups studied. Ozone levels during our study period did not differ greatly from those of other studies in London $[11,12]$ so the reasons for a failing to find significant associations are not clear.

The strong association between $\mathrm{CO}$ and visits by the elderly for respiratory complaints may be an indicator of an association between $\mathrm{CO}$ and cardiovascular disease as much as an association with respiratory disease. The majority of the visits by the elderly were for the nonspecific complaint of "difficulty in breathing" (68\%). Carbon monoxide has been identified as being associated with increased admissions for acute myocardial infarction and other circulatory diseases in London [28].

In conclusion, we have found highly statistically significant associations between the number of daily visits to accident and emergency departments for respiratory complaints and measures of outdoor air pollution. These associations persist after adjustment for the effects of temperature, humidity, seasonal and weekly patterns in attendances. The strongest associations were found in children and in visits for asthma in particular. The main pollutants implicated are sulphur dioxide, particles with a median aerodynamic diameter of $<10 \mu \mathrm{m}$ and specifically for asthma, nitrogen dioxide.

\footnotetext{
Acknowledgements. This work is part of an ongoing project to investigate the effects, and likely healthcare costs, of outdoor air pollution on mortality, hospital admissions, visits to A\&E departments and GP consultations in London. The project team comprises H.R. Anderson (Principal Investigator), D.P. Strachan, J.M. Bland, R.W. Atkinson and S. Bremner (St George's Hospital Medical School, London); A. Haines and S. Hajat (University College London, London); A. McMichael (London School of Hygiene and Tropical Medicine, London); J.S. Bower (AEA NETCEN, Oxfordshire); and J. Emberlin (Pollen Research Unit, Worcester). The authors are grateful to J. Taylor, C. Chazot and J. Blake for their diligent work collecting the data and to R. Newson, J. Poloniecki, L. Limb, P. Haigh, and I. Carey for statistical advice and computing support.
}

\section{References}

1. Anonymous. Mortality and morbidity during the London fog of December 1952. London, HMSO, 1954; Report no. 95 on public health and medical subjects.

2. Quality of Urban Air Review Group. Urban air quality in the United Kingdom. Bradford, Department of the Environment, 1993.

3. Brunekreef B, Dockery DW, Krzyzanowski M. Epidemiologic studies on short-term effects of low levels of major ambient air pollution components. Environ Health Perspect 1995; 103: Suppl. 2, 3-13.

4. Touloumi G, Katsouyanni K, Zmirou D, et al. Short-term effects of ambient oxidant exposure on mortality: a combined analysis within the APHEA project. Air Poll- 
ution and Health: a European Approach. Am J Epidemiol 1997; 146: 177-185.

5. Spix C, Anderson HR, Schwartz J, et al. Short-term effects of air pollution on hospital admissions for respiratory diseases in Europe: a quantitative summary of APHEA study results. Arch Environ Health 1998; 53: 5464.

6. Schwartz J. Air pollution and daily mortality: a review and meta analysis. Environ Res 1994; 64: 36-52.

7. Anderson HR, Spix C, Medina S, et al. Air pollution and daily admissions for chronic obstructive pulmonary disease in 6 European cities: results from the APHEA project. Eur Respir J 1997; 10: 1064-1071.

8. Katsouyanni K, Touloumi G, Spix C, et al. Short-term effects of ambient sulphur dioxide and particulate matter on mortality in 12 European cities: results from time series data from the APHEA project. Air Pollution and Health: a European Approach. BMJ 1997; 314: 16581663.

9. Wordley J, Walters S, Ayres JG. Short term variations in hospital admissions and mortality and particulate air pollution. Occup Environ Med 1997; 54: 108-116.

10. Lebowitz MD. Epidemiological studies of the respiratory effects of air pollution. Eur Respir J 1996; 9: 1029-1054.

11. Ponce de Leon A, Anderson HR, Bland JM, Strachan DP, Bower J. Effects of air pollution on daily hospital admissions for respiratory disease in London between 1987-88. and 1991-92. J Epidemiol Community Health 1996; 50: Suppl. 1, s63-s70.

12. Anderson HR, Ponce de Leon A, Bland JM, Bower JS, Strachan DP. Air pollution and daily mortality in London: 1987-92. BMJ 1996; 312: 665-669.

13. Bates DV, Baker-Anderson M, Sizto R. Asthma attack periodicity: a study of hospital emergency visits in Vancouver. Environ Res 1990; 51: 51-70.

14. Cody RP, Weisel CP, Birnbaum G, Lioy PJ. The effect of ozone associated with summertime photochemical smog on the frequency of asthma visits to hospital emergency departments. Environ Res 1992; 58: 184-194.

15. Schwartz J, Slater D, Larson TV, Pierson WE, Koenig JQ. Particulate air pollution and hospital emergency room visits for asthma in Seattle. Am Rev Respir Dis 1993; 147: 826-831.

16. Castellsague J, Sunyer J, Saez M, Anto JM. Short-term association between air pollution and emergency room visits for asthma in Barcelona. Thorax 1995; 50: 10511056.

17. Buchdahl R, Parker A, Stebbings T, Babiker A. Association between air pollution and acute childhood wheezy episodes: prospective observational study. $B M J$ 1996; 312: 661-665.

18. Delfino RJ, Murphy-Moulton AM, Burnett RT, Brook JR, Becklake MR. Effects of air pollution on emergency room visits for respiratory illnesses in Montreal, Quebec. $\mathrm{Am} J$ Respir Crit Care Med 1997; 155: 568-576.

19. Stieb DM, Burnett RT, Beveridge RC, Brook JR. Association between ozone and asthma emergency department visits in Saint John, New Brunswick, Canada. Environ Health Perspect 1996; 104: 1354-1360.

20. Rossi OV, Kinnula VL, Tienari J, Huhti E. Association of severe asthma attacks with weather, pollen, and air pollutants. Thorax 1993; 48: 244-248.

21. Weisel CP, Cody RP, Lioy PJ. Relationship between summertime ambient ozone levels and emergency department visits for asthma in central New Jersey. Environ Health Perspect 1995; 103: 97-102.

22. Atomic Energy Authority Technology: National Environmental Technology Centre. Air Pollution in the UK: 1994. AEA/RAMP/200015001/1, 1997.

23. Buck SF. A method of estimation of missing values in multivariate data suitable for use with an electronic computer. Royal Stat Soc, Services B 1960; 22: 302-306.

24. Katsouyanni K, Schwartz J, Spix C, et al. Short term effects of air pollution on health: a European approach using epidemiologic time series data: the APHEA protocol. J Epidemiol Community Health 1996; 50: Suppl. 1, S12-S18.

25. Zeger SL. A regression model for time series of counts. Biometrika 1988; 75: 621-629.

26. Venables KM, Allitt U, Collier CG, et al. Thunderstormrelated asthma: the epidemic of 24-25th June 1994. Clin Exp Allergy 1997; 27: 725-736.

27. Tunnicliffe WS, Burge PS, Ayres JG. Effect of domestic concentrations of nitrogen dioxide on airway responses to inhaled allergen in asthmatic patients. Lancet 1994; 344: 1733-1736.

28. Poloniecki JD, Atkinson RW, Ponce de Leon A, Anderson HR. Daily time series for cardiovascular hospital admissions and previous day's air pollution in London, UK. Occup Environ Med 1997; 54: 535-540. 